\section{First record of Okenia pellucida Burn, 1967 (Mollusca: Nudibranchia) from India}

\author{
Vishal Bhave ${ }^{1} \&$ Deepak Apte ${ }^{2}$ \\ ${ }^{1}$ Scientist 'B', ${ }^{2}$ Deputy Director (Conservation) \\ Bombay Natural History Society, Hornbill House opp. Lion Gate, \\ Shaheed Bhagat Singh Road, Mumbai 400 001, Maharashtra, \\ India \\ Email: ${ }^{1}$ vishalbhave@gmail.com (corresponding author), \\ spiderconch@gmail.com
}

India has a large and diverse coastal area in terms of biological as well as habitat diversity. India is bracing for large coastal infrastructure development, which will impact intertidal biodiversity and the Maharashtra coast is not an exception. It is therefore essential to develop baseline information on inter-tidal marine biodiversity. As part of this effort, scientists are working on various taxa, and opisthobranchs are one such group under study. They are beautifully colored with highly diverse adaptations to compensate for the loss of shell during the course of evolution. Opisthobranchs are poorly studied from Indian coasts, and recent work on

Date of publication (online): 26 November 2012

Date of publication (print): 26 November 2012

ISSN 0974-7907 (online) | 0974-7893 (print)

Editor: N Yonow

Manuscript details:

Ms \# 02929

Received 27 August 2011

Final received 19 June 2012

Finally accepted 10 October 2012

Citation: Vishal Bhave \& Deepak Apte (2012). First record of Okenia pellucida Burn, 1967 (Mollusca: Nudibranchia) from India. Journal of Threatened Taxa 4(14): 3362-3365.

Copyright: (C) Vishal Bhave \& Deepak Apte 2012. Creative Commons Attribution 3.0 Unported License. JoTT allows unrestricted use of this article in any medium for non-profit purposes, reproduction and distribution by providing adequate credit to the authors and the source of publication.

Acknowledgements: The present study would not have been possible without the constant support of Director and staff of the BNHS. We thank Dr. Bill Rudman, Dr. Richard Willan and Dr. Terry Gosliner for their support in the form of personal communications, discussions, species validation and also for providing literature. Authors would also like to thanks Dr. Dennis Gordon (NIWA, New Zealand) for confirmation of the bryozoan Zoobotryon verticillatum from Ratnagiri. Mr. Vishwas Shinde and Rajendra Pawar provided valuable field assistance in searching for cryptic opisthobranchs during the survey. Lastly authors would like to thanks referees for the constructive comments.

urn:Isid:zoobank.org:pub:14083759-A12C-45CC-A50F-A513EB94FACA

OPEN ACGESS | FREE DOWNLOAD opisthobranchs was carried out by Apte (2009), Apte et al. (2010), Apte \& Salahuddin (2011), Bhave $\&$ Apte (2010) and Ramakrishna et al. (2010). The present paper deals with a record of the goniodorid nudibranch Okenia pellucida Burn, 1967. There are very few records of goniodorids from India (Alder \& Hancock 1864; Winckworth 1946; Ramakrishna et al. 2010). Table 1 provides the checklist of goniodorid species hereto recorded from the Indian coasts.

\section{Materials and Methods}

Direct search method was used to find the opisthobranchs by turning over rocks and boulders in the intertidal region covering various microhabitats such as rock pools and rocky areas. These specimens were collected along with the host bryozoan (Zoobotryon verticillatum delle Chiaje, 1828) and kept live in aquaria for a week to study their behavior. Photographs, both underwater and in the laboratory, were captured using a Canon G10 camera. The specimens were preserved directly in 95\% ethyl alcohol and deposited in BNHS's opisthobranch collection. The radula was extracted by dissolving the buccal mass in sodium hypochlorite and images were captured using a Leica Microsystem Microscope (Leica EZ 4D and Leica DM 750). The series of microscopic images captured at various depths of field were then combined using the open source software package Combine ZP (http://www. hadleyweb.pwp.blueyonder.co.uk/CZP/News.htm).

\section{Descriptions}

\section{Okenia pellucida Burn, 1967}

(Images 1 - On prey Zoobotryon verticillatum; 2 Lateral side; 3 - Dorsal side; 4 - Whole radula, scale bar $200 \mu \mathrm{m} ; 5$ - Innermost radular teeth from new/old rows $23^{\text {rd }}$, scale bar $200 \mu \mathrm{m} ; 6$ - Egg case).

Material: A single specimen was used for radula preparation from each of the following collections: (a) Eight specimens collected from the rocky shore near Lighthouse, Ratnagiri on 22.ii.2010 (Catalog Id BNHS-Opistho-296 [voucher]) on Zoobotryon verticillatum; (b) Two specimens from Mirya, Ratnagiri 06.v.2011 (Catalog Id BNHS-Opistho-627 [voucher]) on Zoobotryon verticillatum. 


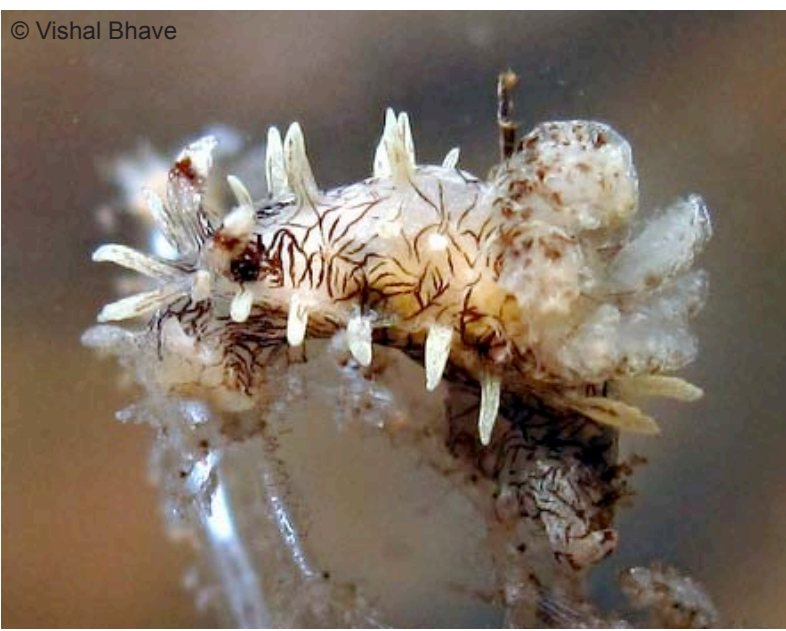

Image 1. On prey Zoobotryon verticillatum

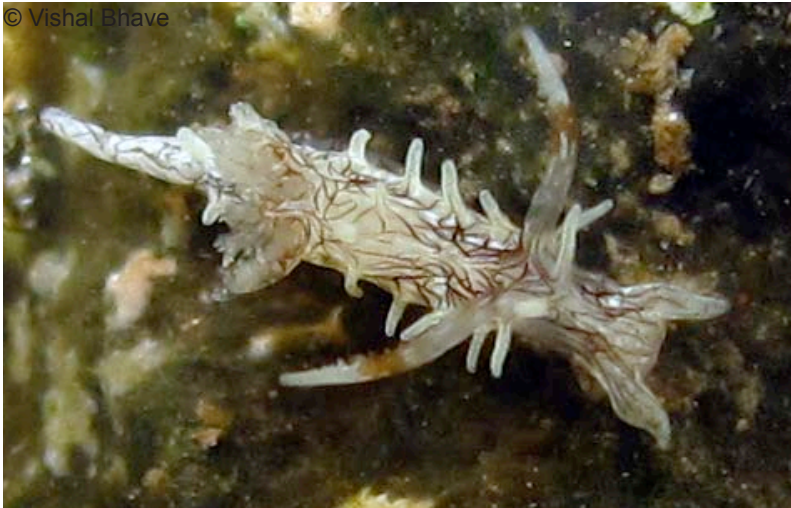

Image 3. Dorsal side

Size: 6-20 mm

Geographic Distribution: Rudman (2004a) and Gosliner (2004) in their reviews have provided the distribution of this species. The species is known to be widely distributed in New Zealand, Australia, Hawaii, Japan, Palmyra Atoll, Oceania, Malaysia and United Arab Emirates.

Morphology (Images 1-3): The animal is somewhat elongated with a long tail which was observed to be

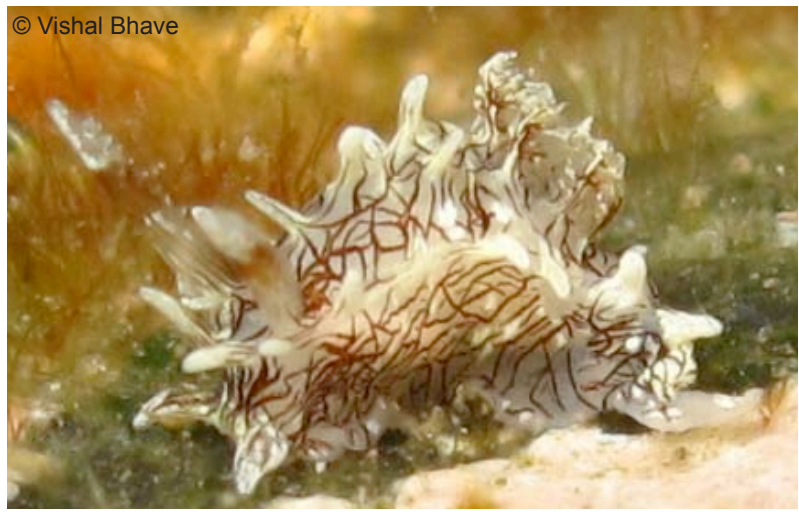

Image 2. Lateral side

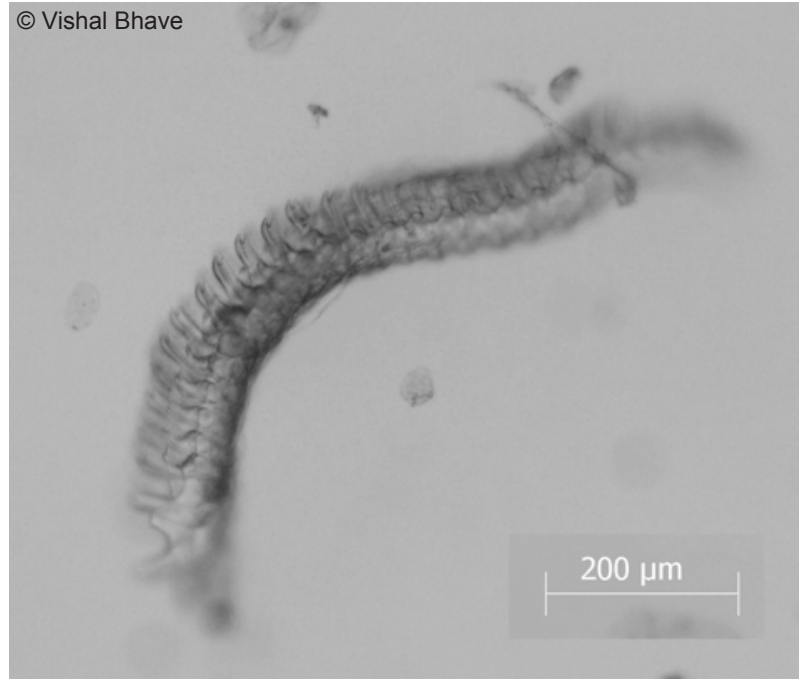

Image 4. Whole radula (light microscope photograph)

helpful to cling onto the bryozoan host while feeding. There are 10-12 lateral papillae on each side of the mantle and 5-6 papillae on the dorsal side of the notum. The eight gills are large, bi-pinnate and form a thick rosette. The head can be distinguished easily and the oral tentacles are triangular. The rhinophores are long, approximate $2.5-3 \mathrm{~mm}$, almost 1.5 times the length of the head when alive. Two small papillae

Table 1. Goniodorid fauna recorded from India

\begin{tabular}{|c|l|l|l|}
\hline SNo & Name of the species & Recorded by & Locality \\
\hline 1 & Goniodoridella savignyi Pruvot-Fol, 1933 & Ramakrishna et al. 2010 & Andaman Island \\
\hline 2 & Goniodoris aspersa Alder \& Hancock, 1864 & Alder \& Hancock 1864 & Vishakhapattanam \\
\hline 3 & Goniodoris citrina Alder \& Hancock, 1864 & Alder \& Hancock 1864 & Vishakhapattanam \\
\hline 4 & Goniodoris modesta Alder \& Hancock, 1864 & Alder \& Hancock 1864 & Vishakhapattanam \\
\hline 5 & Goniodoris kolabana Winckworth, 1946 & Winckworth 1946 & Mumbai, Maharashtra \\
\hline
\end{tabular}




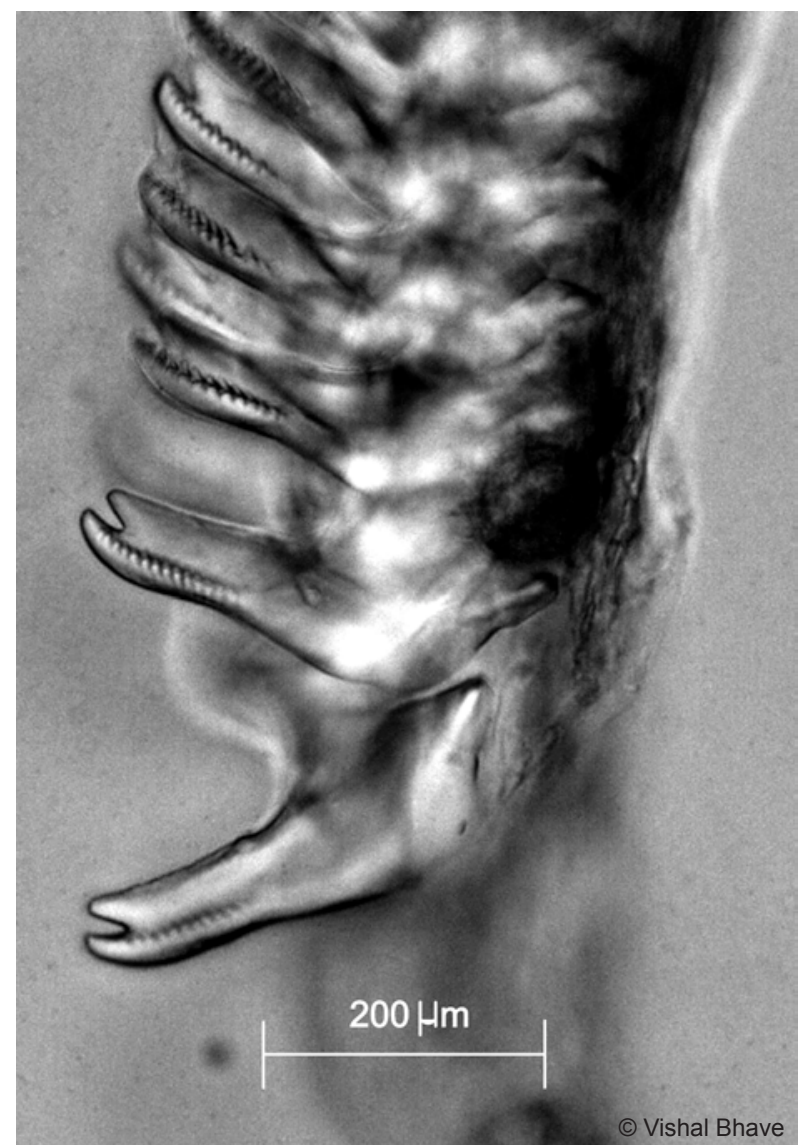

Image 5. Lateral view of innermost radular teeth from rows 23- light micrograph processed with Combine ZP

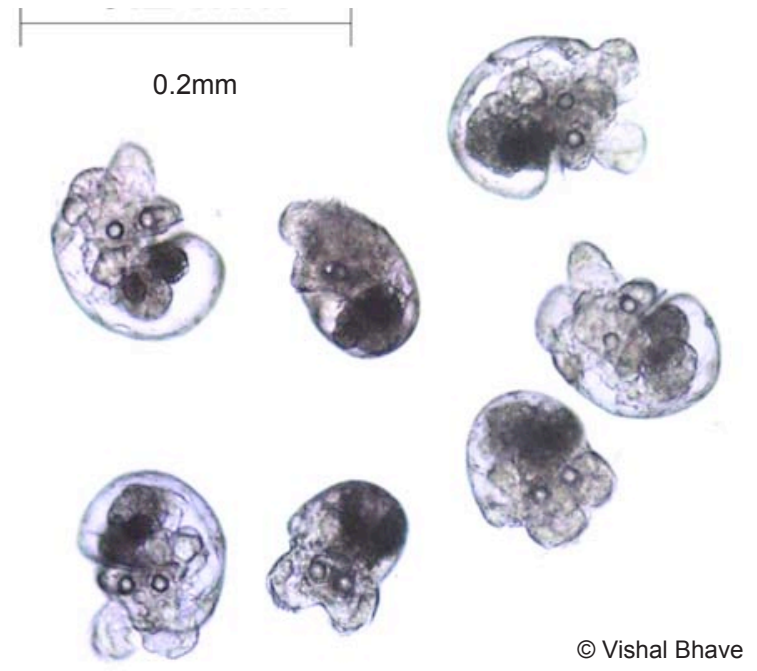

Image 7. Free swimming veligers (with eye spots and larval shells)

are present on the posterior side of each rhinophore extending up to half its height. There are two papillae in front of each rhinophore.

Color: The overall color of the mantle is creamy

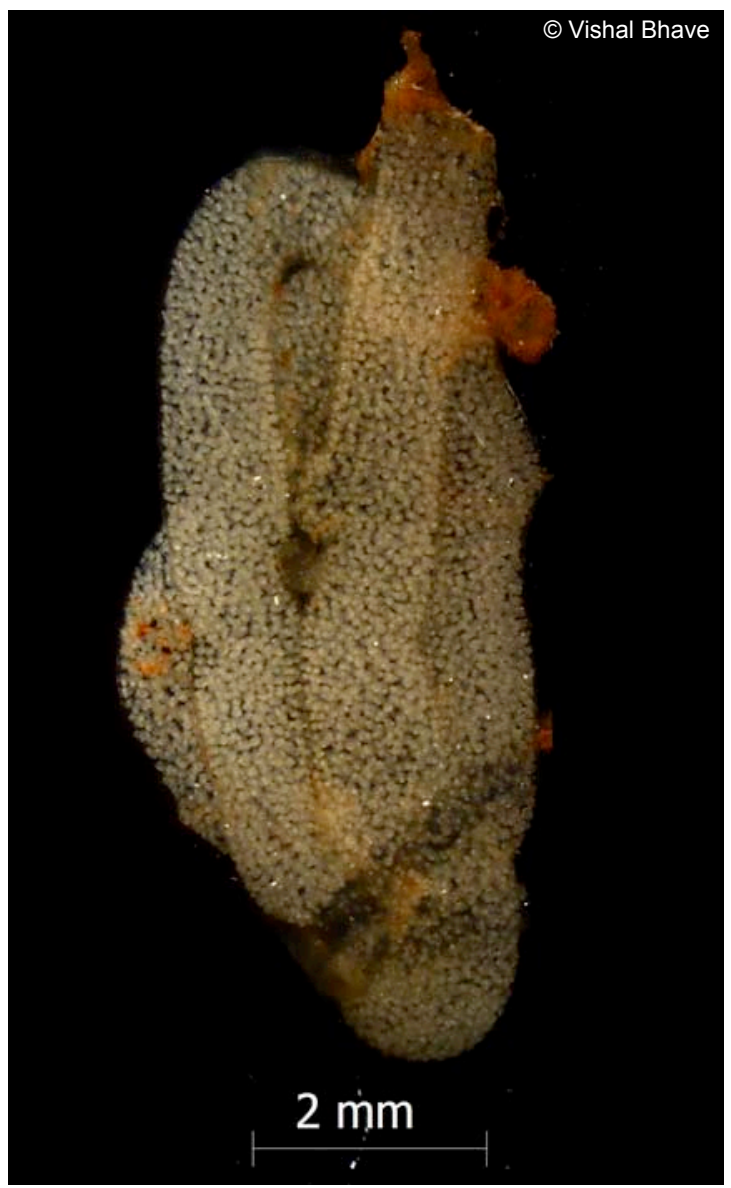

Image 6. Egg case

white and randomly marked with brown wavy lines. The rhinophores are creamy white; a subapical band of brownish-orange is present on rhinophore and is $1 / 4^{\text {th }}$ of rhinophore height. In some specimens, the base of the rhinophores shows an aggregation of brown wavy lines. Rhinophore tips are pale followed by pale brownish band which is one-fourth in size than that of the rhinophore. Gills are whitish and in some specimens with brownish pigmentation at the base. Oral veil is triangular with oral tentacles short with rounded corners.

Radular morphology (Images 4-5): The radular formula of an $18 \mathrm{~mm}$ animal was $23 \times 1.1 .0 .1 .1$. The first lateral tooth is an elongated bicuspid blade and inner margin of inner cusp is denticulate with approximately $10-12$ denticles. The size of teeth at its longest edge is $89.37 \mu \mathrm{m}$. Breadth at blade portion is around $15.20 \mu \mathrm{m}$.

Egg case and Larvae (Images 6-7): The egg cases are randomly laid in the form of white tubular strings. These are loosely attached to the host bryozoans and 
thus can be easily detached. It is due to the network structure of the Zoobotryon verticillatum colony that the egg cases become entangled and protected. Eggs are large and can be seen by the naked eye in freshly laid egg cases. The length of the string varies between $16-20 \mathrm{~mm}$ and the width is around $1-1.5 \mathrm{~mm}$ (Image $6)$.

Free swimming larvae were observed in the egg cases collected from the field. However, these eggs were not freshly laid. The larvae were moving in the egg capsules. The larvae measured around $0.1 \mathrm{~mm}$ in diameter, when these were free. Large eyespots and clear larval vail with cilia and transparent large shell were easy to spot (Image 7).

\section{Discussion}

This is the first record of Okenia pellucida from the Indian subcontinental waters. This species is known to be an oblicate associate of the fouling bryozoans Zoobotryon verticillatum (Atkinson \& Atkinson 2000; Rudman 2004a,b). During the present study, we also observed O. pellucida associated with Zoobotryon verticillatum.

There are a few records of Zoobotryon verticillatum along the coastal shores of India (Swami \& Udhayakumar 2010; BioSearch 2011) confined mostly to the east coast of India. This species was recorded from the Mumbai coast recently (Swami \& Udhayakumar 2010) and it is the only known record of it on the west coast of India. However, this species is possibly widespread along other parts of India, thus the distribution of $O$. pellucida could be widespread along the coastline. More intensive surveys can throw light on its distribution along the Indian coast.

\section{REFERENCES}

Alder, J. \& A. Hancock (1864). Notice on the collection of Nudibranchiate Mollusca made in India by Walter Eliot Esq. with descriptions of several new genera and species. Transaction of Zoological Society of London 5: 117-147.

Atkinson, D. \& L. Atkinson (2000). Bryozoan food of Okenia pellucida. [message in] Sea Slug Forum. Australian Museum,
Sydney. <Available from: http://www.seaslugforum.net/ find/1987> Online version dated 29 February 2000.

Apte, D. (2009). Opisthobranch fauna of Lakshadweep islands, India, with 52 new records to Lakshadweep and 40 new records to India: part 1. Journal of the Bombay Natural History Society 106(2): 162-175.

Apte, D., V. Bhave \& D. Parasharya (2010). An annotated and illustrated checklist of the opisthobranch fauna of Gulf of Kutch, Gujarat, India with 21 new records for Gujarat and 13 new records for India: part 1. Journal of the Bombay Natural History Society 107(1): 14-23.

Apte, D. \& V.K. Salahuddin (2011). Record of Hexabranchus sanguineus (Rüppell and Leuckart, 1828) from Lakshadweep Archipelago, India. Journal of the Bombay Natural History Society 107(3): 261-262.

Bhave, V. \& D. Apte (2010). 'Opisthobranch fauna from west coast of India, Abstracts World Congress of Malacology, Phuket'. Tropical Natural History, Supplement 3, p.54.

Burn, R.F. (1967). Descriptions of two new species of Okenia (Nudibranchia, Doridacea) from south-eastern Australia. Proceedings of the Royal Zoological Society of New South Wales, 1965/1966, pp.52-57.

BioSearch (2011). Bioinformatics Centre, National Institute of Oceanography, Goa, India <http://www.biosearch.in/ publicOrganismPage.php?id=58116> On-line version dated 12 May 2011

Gosliner, T.M. (2004). Phylogenetic systematics of Okenia, Sakishimaia, Hopkinsiella and Hopkinsia (Nudibranchia: Goniodorididae) with descriptions of new species from the tropical Indo-Pacific. Proceedings of the California Academy of Sciences, 55, 125-161+29 figs.

Ramakrishna, C.R. Sreeraj, C. Raghunathan, C. Sivaperuman, J.S.Y. Kumar, R. Raghuraman, T. Iammanuel \& P.T. Rajan (2010). Guide to opisthobranchs of Andaman and Nicobar Islands. Zoological Survey of India, Kolkata, 143pp.

Rudman, W.B. (2004a). Further species of the opisthobranch genus Okenia (Nudibranchia: Goniodorididae) from the Indo-West Pacific. Zootaxa 695: 1-70.

Rudman, W.B. (2004b). Okenia pellucida Burn, 1967. [In] Sea Slug Forum. Australian Museum, Sydney. <Available from http://www.seaslugforum.net/factsheet/okenpell $>$ On-line version dated 12 December 2004.

Swami, B.S. \& M. Udhayakumar (2010). Seasonal influence on settlement, distribution and diversity of fouling organisms at Mumbai harbour. Indian Journal of Marine Sciences 39(1): 57-67.

Winckworth, H.C. (1946). A new Goniodoris from Bombay. Journal of Molluscan Studies 27(2): 59-61. 